
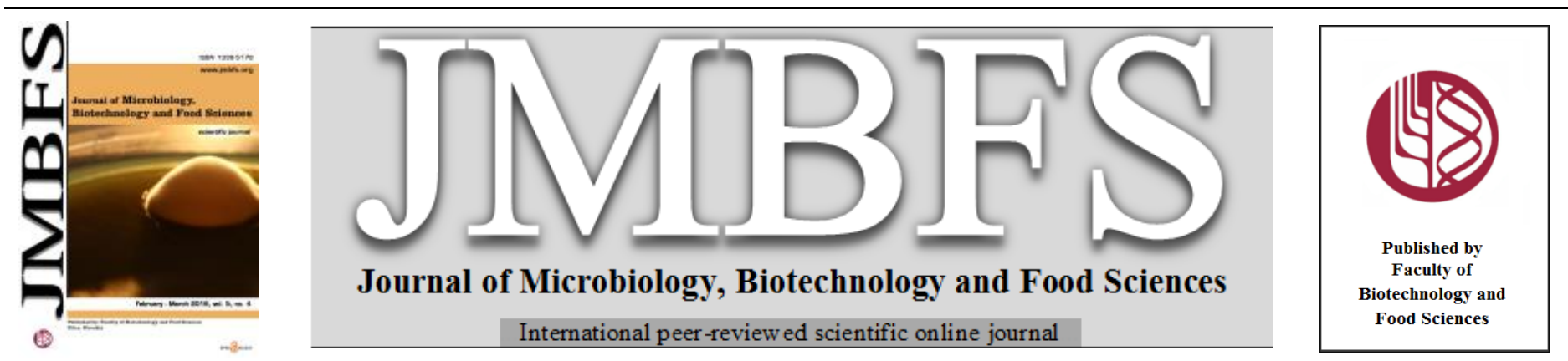

\title{
ANTIMICROBIAL AND PHYTOCHEMICAL ATTRIBUTES OF DENNETTIA TRIPETALA F. BAKER ROOT AND BARK EXTRACTS
}

\author{
Kenechukwu Obumneme Akabueze, ${ }^{l}$ MacDonald Idu ${ }^{I}$, Joseph Omorogiuwa Erhabor* ${ }^{1}$, and Odaro Timothy ${ }^{I}$
}

Address(es): Joseph Erhabor,

${ }^{1}$ University of Benin, Faculty of Life Sciences, Department of Plant Biology and Biotechnology, P.M.B.1154, 300001 Benin City, Edo State, Nigeria. +2348077979390

*Corresponding author: erhaborjoseph@uniben.edu

doi: 10.15414/jmbfs.2016.5.4.297-300

\section{ARTICLE INFO}

Received 11. 12. 2013

Revised 6. 10. 2015

Accepted 21. 10. 2015

Published 1. 2. 2016

Regular article open $\partial_{\text {Access }}$

\begin{abstract}
The antimicrobial activities and phytochemical constituents of aqueous and hexane extracts of both the bark and roots of Dennettia tripetala F. Baker (Annonaceae) were determined using routine methods. Flavonoids, saponins, phenolic compounds, volatile oil, carbohydrate and reducing sugars were present in the aqueous extract of the root and bark, but absent in the hexane extracts. The antimicrobial activities of the extracts were tested against bacterial and fungal isolates using agar diffusion method.The commercial antibiotics used as positive reference standards to determine the sensitivity of the isolates were Gentamicin and Fluconazole.The aqueous extract of the root showed inhibitory activity against Escherichia coli, Bacillus subtilis, Staphylococcus aureus, Enterococcus faecalis and Pseudomonas aeruginosa, with zones of inhibition ranging from $0.01 \mathrm{~mm}$ to $30 \mathrm{~mm}$. The aqueous root extract inhibited the growth of Pseudomonas aeruginosa and Enterococcus faecalis with MIC values at $50 \mathrm{mg} / \mathrm{ml}$. The results showed that the aqueous root extract possesed antimicrobial attributes as indicated by its activity on test bactetrial isolates. Phytochemicals were not present in the hexane extracts and the extracts showed no activity against the test organisms.
\end{abstract}

\section{INTRODUCTION}

Records of indigenous knowledge from various parts of the world illustrate an age long tradition of plants being a major bioresource base for health care (Idu $\boldsymbol{e t}$ $\boldsymbol{a l} ., 2000 a)$. It has been found that some drugs are synthesized from plants (Idu $\boldsymbol{e t}$ al., 2007). A medicinal plant can be defined as any plant which in one or more of its organs contain substances that can be used for therapeutic purpose or which are precursors for the synthesis of useful drugs (Sofowora, 1982). Plant secondary metabolites constitute one of the most numerous and widely distributed groups of substances in the plant kingdom and have been known to be responsible for the therapeutic activities of medicinal plants (Ataman et al., 2002). Phytomedicines derived from plants have shown great promises in the treatment of intractable infections (Iwu et al., 1999) and in vitro screening methods could provide the needed preliminary observations necessary to select crude plant extracts with potentially useful properties for further chemical and pharmacological investigations (Ozumba, 2003; Pessini et al., 2003). Dennettia tripetala Baker F. (pepper fruit) belongs to the family Annonaceae. It is found in the tropical rainforest region of Nigeria and occassionally in the savanna region (Okwu et al., 2005). The plant flourishes at the onset of the rain, from April through June (Umoh, 1998). It is a woody plant of about $7 \mathrm{~m}$ in height with simple leaves. The young leaves are chewed on account of their pungent spicy taste. The fruits are initially green then turn red on ripening between April and May and have a peppery spicy taste and are chewed for this property. The leaves are used to treat mild fever with other herbs such as the leaves of mango (Gill, 1992). The young stems of this plant are also used as chewing stick by patients with fever to help improve their appetite. Pharmacologically, the oil extracted from the fruits of the plant when mixed with fresh leaves of mango is used in treating fever (Gill, 1992).

The aim and objective of this study was to determine the antimicrobial activity and the phytochemical consitiuents of hexane and aqueous extracts of bark and roots of D. tripetala.

\section{MATERIAL AND METHODS}

\section{Plant materials}

The barks and roots of $D$. tripetala were collected in the month of August, 2010 from Umudioka in Dunukofia L.G.A. of Anambra State and was identified by Professor M. Idu of the Department of Plant Biology and Biotechnology, University of Benin, Benin City. The plant parts were dried at an average temperature of $45^{\circ} \mathrm{C}$ for 3 days using a 50L GALLENKAMP hot box oven (model; N9615-50, 250 ${ }^{\circ} \mathrm{C}$ ) manufactured by Rigal Bennett. The dried samples were macerated to fine particles. The weighed powdered samples $(550 \mathrm{~g}$ of bark and $165 \mathrm{~g}$ of root) were extracted with $2100 \mathrm{ml}$ hexane for bark and $700 \mathrm{ml}$ for root with occasional stirring for $48 \mathrm{hrs}$ for maximum dissolution after which it was sieved through a Whatman filter paper to obtain a solution. The solution was concentrated to dryness using 10L GALLENKAMP water bath(model; S868950) manufactured by Rigal Bennett. The residue were air-dried to remove any remaining hexane before they were subjected to another extraction using distilled water. The extraction was done for $18 \mathrm{~h}$ using $2800 \mathrm{ml}$ of boiled distilled water. They were filtered and then concentrated over Gallenkamp water bath. The four extracts were stored in refrigerator until required for use.

\section{Standardization and preparation of the microbial innocula}

The stock culture were obtained from the Department of Pharmaceutical Microbiology, Faculty of Pharmacy, University of Benin. Five (5) bacterial strains; Bacillus subtilis, Pseudomonas aeruginosa, Escherichia coli, Staphylococcus aureus and Enterococcus faecalis and two (2) fungi strains; Candida albicans and Microsporium audouinii were used.

All the test organisms (bacterial and fungal isolates) were sub-cultured on freshly prepared nutrient agar plates and potato dextrose agar plates and incubated for $24 \mathrm{~h}$ and $48 \mathrm{~h}$ respectively. Following the slightly modified method of Vandepitte et al. (2003), the inocula were standardized by transfering parts of the streaked colonies into $5 \mathrm{ml}$ of sterile nutrient broth in test tubes and incubated for $3 \mathrm{~h}$ at $37^{\circ} \mathrm{C}$. The bacteria and fungi suspension growth were appropriately compared to that of a freshly prepared barium sulphate solution $(0.5 \mathrm{ml}$ of $1 \%$ barium in Chloride to $99.5 \mathrm{ml}$ of $1 \% \mathrm{H}_{2} \mathrm{SO}_{4}(0.36$ Normal). The obtained turbidity was adjusted by adding more sterile nutrient broth to match the 0.5 Mcfarland 
standard $\left(10^{6} \mathrm{cfu} / \mathrm{ml}\right)$. After incubation, $1 \mathrm{ml}$ of the standardized cultures of the microbial isolates were inoculated onto the surface of freshly prepared nutrient agar plates (for the bacterial isolates) and sabouraud dextrose agar plates (for the fungal isolates) with the aid of sterile bent glass rod.

\section{Test for antimicrobial activity}

The diluted aqueous and hexane extracts of the root and bark of the plant were tested for their antimicrobial properties using the punch hole method (Stoke, 1975). The concentrations used were 400, 200, 100 and $50 \mathrm{mg} / \mathrm{ml}$. The antibiotics; gentamicin (at a concentration of $5 \mathrm{mg} / \mathrm{ml}$ ) and commercia fluconazole (at a concentration of $5 \mathrm{mg} / \mathrm{ml}$ ), were used as positive controls for bacterial and fungal isolates respectively. The standard antiobiotic sensitivity discs (Gentamicin and Fluconazole) made by Asodisks Atlas Diagnostics, Enugu, Nigeria were purchased from a chemical laboratory store in Benin city and used after which the plates were incubated overnight at $37^{\circ} \mathrm{C} \pm 2{ }^{\circ} \mathrm{C}$ and $28^{\circ} \mathrm{C} \pm 2{ }^{\circ} \mathrm{C}$ for bacterial and fungal cultures respectively. At the end of the incubation period, the diameter of the inhibition zone(s) were measured using meter rule and recorded.

\section{Minimum Inhibitory Concentration (MIC) Determination}

The minimum inhibitory concentration (MIC) of the crude extracts were determined by adapting the punch hole method as described by Stokes (1975) and decreased concentrations of the extracts i.e. $200,100,50,25$ and $12.5 \mathrm{mg} / \mathrm{ml}$ were utilized. The least concentration of the extract which inhibited the growth of the inocula was considered as the minimum inhibitory concentration.

\section{Phytochemical screening of the extracts of the bark and root}

Phytochemical screening of the aqueous and hexane extracts of the bark and root were conducted according to standard procedures as described by Trease and Evans (1996). The respective extracts were analysed for the presence of alkaloids, saponins, tannins, volatile oils, anthracene, flavonoids, reducing sugars, carbohydrates, cyanogenetic glycerides, phenolic compounds.

\section{Data analysis}

Results were expressed as means \pm standard error of means [S.E.M] and level of significance between means were computed by student's t-test using SPSS 14.00 computer software package. The level of significance was determined at 0.05 .

\section{RESULTS}

The test microbial isolates showed varying degrees of response towards various concentrations of Dennettia tripetala aqueous extract of the bark. The maximal or highest inhibitory zone $(0.09 \mathrm{~mm} \pm 0.01)$ was shown by $P$. aeruginosa exposed to $400 \mathrm{mg} / \mathrm{ml}$ concentration of aqueous bark extract (Tab. 1). P. aeruginosa , E faecalis and $E$. coli elicited the least zone of inhibition $(0.01 \mathrm{~mm} \pm 0.00)$ agains $50 \mathrm{mg} / \mathrm{ml}$ and $100 \mathrm{mg} / \mathrm{ml}$ aqueous bark extract concentrations (Tab.1). The observed differences in the mean inhibitory zones was significant with the zone elicited by $P$. aeruginos $a$ and $E$. coli being responsible.

Table 1 The effect of aqueous extract of the bark of D. tripetala on the test organisms at various concentrations

\begin{tabular}{|c|c|c|c|c|}
\hline \multirow{2}{*}{ Test organisms } & \multicolumn{4}{|c|}{ Zones of inhibition (mm) } \\
\hline & $400 \mathrm{mg} / \mathrm{ml}$ & $200 \mathrm{mg} / \mathrm{ml}$ & $100 \mathrm{mg} / \mathrm{ml}$ & $50 \mathrm{mg} / \mathrm{ml}$ \\
\hline Bacillus subtilis & $0.03^{\mathrm{a}} \pm 0.02$ & $0.03^{\mathrm{a}} \pm 0.01$ & NMZI & NMZI \\
\hline $\begin{array}{l}\text { Pseudomonas } \\
\text { aeruginosa }\end{array}$ & $0.09^{\mathrm{a}} \pm 0.01$ & $0.05^{\mathrm{a}} \pm 0.01$ & $0.02^{\mathrm{b}} \pm 0.01$ & $0.01^{\mathrm{b}} \pm 0.00$ \\
\hline Escherichia coli & $0.02^{\mathrm{a}} \pm 0.01$ & NMZI & $0.01^{\mathrm{a}} \pm 0.00$ & NMZI \\
\hline $\begin{array}{l}\text { Staphylococcus } \\
\text { aureus }\end{array}$ & $0.05^{\mathrm{a}} \pm 0.01$ & $0.04^{\mathrm{a}} \pm 0.00$ & $0.04^{\mathrm{a}} \pm 0.01$ & NMZI \\
\hline $\begin{array}{l}\text { Enterococcus } \\
\text { feacalis }\end{array}$ & $0.05^{\mathrm{a}} \pm 0.01$ & $0.03^{\mathrm{b}} \pm 0.00$ & $0.02^{\mathrm{b}} \pm 0.03$ & $0.01^{\mathrm{b}} \pm 0.00$ \\
\hline Candida albicans & NMZI & NMZI & NMZI & NMZI \\
\hline Microsporium & NMZI & NMZI & NMZI & NMZI \\
\hline
\end{tabular}

Legends: Values are means \pm S.E.M of two measurements across each zone of inhibition. Means \pm S.E.M with different superscript within a row are significantly different $(\mathrm{P}<0.05)$. NMZI-No Measurable Zone of Inhibition.

The maximal or highest inhibitory zone $(0.05 \mathrm{~mm} \pm 0.01)$ was shown by $P$ aeruginosa exposed to $400 \mathrm{mg} / \mathrm{ml}$ concentration of hexane bark extract (Tab. 2) B. subtilis and $S$. aureus elicited the least zone of inhibition $(0.02 \mathrm{~mm} \pm 0.01)$ against $200 \mathrm{mg} / \mathrm{ml}$ and $400 \mathrm{mg} / \mathrm{ml}$ hexane bark extract concentrations (Tab.2) The observed differences in the mean inhibitory zones was not significant with the zone elicited by $P$. aeruginos $a$ and $B$. subtilis being responsible.
Table 2 The effect of hexane extract of the bark of D. tripetala on the test organisms at various concentrations.

\begin{tabular}{|c|c|c|c|c|}
\hline \multirow{2}{*}{ Test organisms } & \multicolumn{4}{|c|}{ Zones of inhibition (mm) } \\
\hline & $400 \mathrm{mg} / \mathrm{ml}$ & $200 \mathrm{mg} / \mathrm{ml}$ & $100 \mathrm{mg} / \mathrm{ml}$ & $50 \mathrm{mg} / \mathrm{ml}$ \\
\hline Bacillus subtilis & $0.04^{\mathrm{a}} \pm 0.01$ & $0.02^{\mathrm{a}} \pm 0.01$ & NMZI & NMZI \\
\hline $\begin{array}{l}\text { Pseudomonas } \\
\text { aeruginosa }\end{array}$ & $0.05^{\mathrm{a}} \pm 0.01$ & $0.03^{\mathrm{a}} \pm 0.01$ & NMZI & NMZI \\
\hline Escherichia coli & $0.05^{\mathrm{a}} \pm 0.01$ & NMZI & NMZI & NMZI \\
\hline $\begin{array}{l}\text { Staphylococcus } \\
\text { aureus }\end{array}$ & $0.02^{\mathrm{a}} \pm 0.01$ & NMZI & NMZI & NMZI \\
\hline $\begin{array}{l}\text { Enterococcus } \\
\text { feacalis }\end{array}$ & $0.03^{\mathrm{a}} \pm 0.01$ & NMZI & NMZI & NMZI \\
\hline Candida albicans & NMZI & NMZI & NMZI & NMZI \\
\hline $\begin{array}{l}\text { Microsporium } \\
\text { audouinii }\end{array}$ & NMZI & NMZI & NMZI & NMZI \\
\hline
\end{tabular}

Legends: Values are means \pm S.E.M of two measurements across each zone of inhibition. Means \pm S.E.M with different superscript within a row are significantly different $(\mathrm{P}<0.05)$. NMZI-No Measurable Zone of Inhibition.

The maximal or highest inhibitory zone $(30.00 \mathrm{~mm} \pm 3.00)$ was shown by $P$. aeruginosa exposed to $400 \mathrm{mg} / \mathrm{ml}$ concentration of aqueous root extract (Tab. 3) $S$. aureus and $E$. coli elicited the least zone of inhibition $(0.02 \mathrm{~mm} \pm 0.01)$ against $50 \mathrm{mg} / \mathrm{ml}$ and $100 \mathrm{mg} / \mathrm{ml}$ aqueous root extract concentrations (Tab.3). The observed differences in the mean inhibitory zones was significant with the zone elicited by E. coli, S. aureus, E. faecalis and B. subtilis being responsible.

Table 3 The effect of aqueous extract of the root of D. tripetala on the test organisms at various concentrations.

\begin{tabular}{lcccc}
\hline Test organisms & \multicolumn{5}{c}{ Zones of inhibition $(\mathbf{m m})$} \\
& $\mathbf{4 0 0} \mathbf{m g} / \mathbf{m l}$ & $\mathbf{2 0 0} \mathbf{m g} / \mathbf{m l}$ & $\mathbf{1 0 0} \mathbf{m g} / \mathbf{m l}$ & $\mathbf{5 0} \mathbf{m g} / \mathbf{m l}$ \\
\hline $\begin{array}{l}\text { Bacillus subtilis } \\
\begin{array}{l}\text { Pseudomonas } \\
\text { aeruginosa }\end{array}\end{array}$ & $25.00^{\mathrm{a}} \pm 1.00$ & $23.00^{\mathrm{a}} \pm 1.00$ & $0.09^{\mathrm{b}} \pm 0.01$ & $0.04^{\mathrm{b}} \pm 0.01$ \\
$\begin{array}{l}\text { Escherichia } \\
\text { coli }\end{array}$ & $13.00^{\mathrm{a}} \pm 3.00$ & $27.00^{\mathrm{a}} \pm 2.00$ & $25.00^{\mathrm{a}} \pm 0.50$ & $20.00^{\mathrm{a}} \pm 0.75$ \\
$\begin{array}{l}\text { Staphylococcus } \\
\text { aureus }\end{array}$ & $22.00^{\mathrm{a}} \pm 0.10$ & $10.00^{\mathrm{a}} \pm 0.35$ & $0.02^{\mathrm{b}} \pm 0.01$ & $\mathrm{NMZI}$ \\
$\begin{array}{l}\text { Enterococcus } \\
\text { feacalis }\end{array}$ & $20.00^{\mathrm{a}} \pm 1.00$ & $17.00^{\mathrm{a}} \pm 0.20$ & $16.00^{\mathrm{a}} \pm 1.56$ & $0.02^{\mathrm{b}} \pm 0.01$ \\
$\begin{array}{l}\text { Candida } \\
\text { albicans }\end{array}$ & $\mathrm{NMZI}$ & $\mathrm{NMZI}$ & $16.00^{\mathrm{a}} \pm 0.78$ & $15.00^{\mathrm{a}} \pm 050$ \\
$\begin{array}{l}\text { Microsporium } \\
\text { audouinii }\end{array}$ & $\mathrm{NMZI}$ & $\mathrm{NMZI}$ & $\mathrm{NMZI}$ & $\mathrm{NMZI}$ \\
\hline
\end{tabular}

Legends: Values are means \pm S.E.M of two measurements across each zone of inhibition. Means \pm S.E.M with different superscript within a row are significantly different $(\mathrm{P}<0.05)$. NMZI-No Measurable Zone of Inhibition.

The maximal or highest inhibitory zone $(0.08 \mathrm{~mm} \pm 0.01)$ was shown by $P$ aeruginosa exposed to $400 \mathrm{mg} / \mathrm{ml}$ concentration of hexane root extract (Tab. 4) B.subtilisand $E$. faecalis elicited the least zone of inhibition $(0.02 \mathrm{~mm} \pm 0.01)$ against $100 \mathrm{mg} / \mathrm{ml}$ and $200 \mathrm{mg} / \mathrm{ml}$ hexane root extract concentrations (Tab.4) The observed differences in the mean inhibitory zones was significant with the zone elicited by $B$. subtilis being responsible.

The highest inhibitory zone $(0.08 \mathrm{~mm})$ was shown by $P$. aeruginosa at $400 \mathrm{mg} / \mathrm{ml}$ whilst the least inhibition zone $(0.02 \mathrm{~mm})$ was displayed byB.subtilis and $E$. faecalis at $100 \mathrm{mg} / \mathrm{ml}$ and $200 \mathrm{mg} / \mathrm{ml}$ respectively. The differences in the mean inhibitory zones shown by B. subtilis was not significant $(\mathrm{P}>0.05)$ (Tab. 4).

Table 4 The effect of hexane extract of the root of $D$. tripetala on the test organisms at various concentrations.

\begin{tabular}{|c|c|c|c|c|}
\hline \multirow{2}{*}{ Test organisms } & \multicolumn{2}{|c|}{ Zones of inhibition (mm) } & \multirow[b]{2}{*}{$100 \mathrm{mg} / \mathrm{ml}$} & \multirow[b]{2}{*}{$50 \mathrm{mg} / \mathrm{ml}$} \\
\hline & $400 \mathrm{mg} / \mathrm{ml}$ & $200 \mathrm{mg} / \mathrm{ml}$ & & \\
\hline Bacillus subtilis & $0.05^{\mathrm{a}}+0.01$ & $0.02^{\mathrm{a}} \pm 0.01$ & $0.02^{\mathrm{a}} \pm 0.01$ & NMZI \\
\hline $\begin{array}{l}\text { Pseudomonas } \\
\text { aeruginosa }\end{array}$ & $0.08^{\mathrm{a}} \pm 0.01$ & $0.05^{\mathrm{b}} \pm 0.01$ & NMZ̄ & NMZI \\
\hline Escherichia coli & $0.05^{\mathrm{a}} \pm 0.01$ & $0.04^{\mathrm{a}}+0.01$ & NMZI & NMZI \\
\hline $\begin{array}{l}\text { Staphylococcus } \\
\text { aureus }\end{array}$ & $0.03^{\mathrm{a}} \pm 0.01$ & NMZ̄ & NMZI & NMZI \\
\hline $\begin{array}{l}\text { Enterococcus } \\
\text { feacalis }\end{array}$ & $0.04^{\mathrm{a}} \pm 0.01$ & $0.02^{\mathrm{a}} \pm 0.01$ & NMZI & NMZI \\
\hline Candida albicans & NMZI & NMZI & NMZI & NMZI \\
\hline $\begin{array}{l}\text { Microsporium } \\
\text { audouinii }\end{array}$ & NMZI & NMZI & NMZI & NMZI \\
\hline
\end{tabular}

Legends: Values are means \pm S.E.M of two measurements across each zone of inhibition. Means \pm S.E.M with different superscript within a row are significantly different $(\mathrm{P}<0.05)$. NMZI-No Measurable Zone of Inhibition. 
Gentamicin exhibited inhibitory activity against all the exposed bacterial cultures except $B$. subtilis. The highest inhibition zone $(50 \mathrm{~mm})$ against gentamicin disc was shown by $S$. aureus. Fluconazole did not show any significance inhibition on the fungal test organisms (Tab. 5).

Table 5 Effects of the antibiotics on the test organisms

Test organisms

Zone of inhibition (mm)

\begin{tabular}{|c|c|c|}
\hline & \multicolumn{2}{|c|}{ Gentamicin $(5 \mathrm{mg} / \mathrm{ml})$ Fluconazole $(5 \mathrm{mg} / \mathrm{ml})$} \\
\hline Bacillus subtilis & NMZI & NA \\
\hline Pseudomonas aeruginosa & 13 & NA \\
\hline Escherichia coli & 29 & NA \\
\hline Staphylococcus aureus & 50 & NA \\
\hline Enterococcus feacalis & 20 & NA \\
\hline Candida albicans & NA & NMZI \\
\hline Microsporium audouinii & NA & NMZI \\
\hline
\end{tabular}

NMZI- No Measurable Zone of Inhibition; NA- Not Applicable

The hexane extract of root and bark gave a negative result for all the secondary metabolites whereas the aqueous extracts of root and bark gave positive result for some phytochemicals (Saponin, flavonoids, reducing sugar, carbohydrates, volatile oils, phenolic compounds) (Tab. 6).

Table 6 Summary of the result from the phytochemical analysis of aqueous and hexane extracts of root and bark of Dennettia tripetala

\begin{tabular}{lcccc}
\hline $\begin{array}{l}\text { Phytochemical } \\
\text { constituents }\end{array}$ & Bark & Root & Bark & Root \\
\hline Alkaloids & - & - & - & - \\
Saponins & + & + & - & - \\
Tannins & - & - & - & - \\
Volatile oils & + & + & - & - \\
Anthracene & - & - & - & - \\
Flavonoids & + & + & - & - \\
Reducing sugars & + & + & - & - \\
Carbohydrates & + & + & - & - \\
Cyanogenetic & - & - & - & - \\
glycerides & - & + & - & - \\
Phenolic compounds & + & + & & \\
\hline
\end{tabular}

\section{+ - Present.}

- Absent.

The bacterial isolates all displayed an MIC value against hexane and aqueous root and bark extracts. The minimum inhibitory concentration of the aqueous extract of root to inhibit the bacteria test organisms ranged from $50-400 \mathrm{mg} / \mathrm{ml}$. The lowest MIC of $50 \mathrm{mg} / \mathrm{ml}$ was recorded against $S$. aureus, B. subtilis, E. faecalis and $P$. aeruginosa while the highest MIC of $400 \mathrm{mg} / \mathrm{ml}$ was recorded against $E$. coli, S. aureus and E. feacalis.

Table 7 The minimum inhibitory concentration of aqueous extract of the root of D. tripetala on test organisms.

\begin{tabular}{|c|c|c|c|c|}
\hline \multirow{3}{*}{ Test organisms } & \multicolumn{4}{|c|}{ Concentration of extracts $(\mathrm{mg} / \mathrm{ml})$} \\
\hline & \multicolumn{2}{|c|}{ Aqeous } & \multicolumn{2}{|c|}{ Hexane } \\
\hline & Root & Bark & Root & Bark \\
\hline Staphylococcus aureus & 50 & 100 & 400 & 400 \\
\hline Bacillus subtilis & 50 & 100 & 100 & 200 \\
\hline Escherichia coli & 100 & 100 & 200 & 400 \\
\hline Enterococcus faecalis & 50 & 50 & 200 & 400 \\
\hline Pseudomonas aeruginosa & 50 & 50 & 200 & 200 \\
\hline Candida albicans & $>400$ & $>400$ & $>400$ & $>400$ \\
\hline Microsporum audouinii & $>400$ & $>400$ & $>400$ & $>400$ \\
\hline
\end{tabular}

\section{DISCUSSION}

The aqueous preparation of $D$. tripetala roots exhibited a greater antibacterial activity in comparision with other extracts prepared from the same plant. The antimicrobial activity of $D$. tripetala root can be attributed to the metabolites which it contains. It was observed that sensitivity increased with increasing concentration of the aqueous root extract. The hexane extracts showed little or no activity against the test microorganisms. This might be attributable to the fact that there was no phytochemicals extracted for it to show activity against the test microorganisms. The potency of the extract was comparable to those of antibiotics which are pure substances. The extracts did not show any activity against fungi (i.e. no antifungal activity) probaably due to the high resistant nature of the fungal strain used. The antifungal agent, fluconazole did not show activity against the fungal isolates probably because the strains of the fungi used are resistant to the activity of the antibiotic.

Based on the statistical analysis, there was significant difference between the inhibitory effect of the aqeous root and bark extracts against $P$. aeruginosa, $B$. subtilis, E. coli, S. aureus, E. faecalis. However, there was no significant difference between the inhibitory effect of the hexane bark and root extract. Considering the minimum inhibitory concentration (MIC) values of the aqueous root extract of the plant, the most potent activities were against Staphylococcus aureus, Bacillus subtilis, Escherichia coli, Enterococcus faecalis and Pseudomonas aeruginosa. The ability of the extract to inhibit some of the test bacterial isolates further confirm its traditional medical use by the traditional medical practitioners for the treatment of stomach disturbance and skin infections. Staphyloccocus aureus is known to play a significant role in skin diseases including superficial and deep follicular lesion, so the strong activity of the aqueous root extract of $D$. tripetala indicated that it could be effective against skin diseases. The antimicrobial activity observed for the aqueous extract of the root may be due to the fact that roots store more of the chemical compounds produced by plants than the bark. The root has cells that function in storing or accumulating certain active secondary metabolites and also due to the solvent used in extraction (i.e. distilled water) which is a polar solvent. However, the mechanisms through which the extract from the present study exert its antimicrobial activities requires further elucidation. The hexane extracts of the root and bark showed no activity against the test organisms.

A great number of chemicals found in plants have been said to be responsible for the medicinal properties of the plants. Saponins have been known to provide the starting material for the synthesis of corticosteroids and oral contraceptives (Trease and Evans, 1996), which are drugs that affect the female hormones This observation supported the usage of $D$. tripetala in preparation of dishes for pregnant and postpartum women and also in prevention of nausea in pregnant women according to Nwinuka and Nwiloh (2009). Volatile oil (i.e. Bphenylnitroethane) present in the plant parts, gives it its typical fragrance as well as for its pungency. These volatile oils together with phenolic compounds have antibacterial property which supports the use of the plant as antibacterial. Flavonoids are strong antioxidants, also found to be effective antimicrobial substances in vitro againsta wide range of microorganisms by inhibiting the membrane bound enzymes (Cowan, 1999). This support the use of the plant as antibacterial drugs. Ejechi and Akpomedaye, (2005) reported that essential oi and phenolic acid of pepper fruit can play a significant role in food preservation and protection against pathogens when they tested the extracts on fresh beef. The findings in this study agree with earlier studies that, not all phytochemicals are present in all plant parts and that those present differ according to the type of extracting solvent used (Ayinde et al., 2007 ; Tijjani et al., 2009). Based on this, Okwu et al., (2005) using ethanolic extract of the fruit of D. tripetala isolated phenanthrene alkaloid; uvariopsine, which was the first report of isolation of uvariopsine from the family Annonaceae. However, in the present study, the aqueous and hexane extracts did not show the presence of alkaloids (Table 6).

\section{CONCLUSION}

The presence of the phytochemicals in the aqueous extract of root has shown that D. tripetala root can be very effective against some bacteria making it a good antibacterial agent. The aqueous extract of the root contained active phytochemicals as measured by the degree of inhibition and number of microorganisms inhibited. Therefore it may be considered as potential antimicrobial agents for use in food products and post harvest disease control However, further studies are recommended on the chemical characterization as well as bio-activity guided studies of the aqeous extract of the root.

\section{REFERENCES}

Ataman, J. E., Idu, M., Okoro Mary-Anne, O., Akinbo, S. F., Ayinde, B. A., Ibe N. I., Idu, F. K., Akhigbe, A. O., \& Omoregie, E. S. (2002). Preliminary studies on the phytochemistry and efficacy of extract of the bark of Spondia mombin (L). on induced cancer in rats. Annals of Biomedical Sciences, 1, 100-110. http://dx.doi.org/10.4314/abs.v1i2.40629

Ayinde, B. A., Onwukaeme, D. N., \& Omogbai, E. K. I. (2007). Isolation and characterization of two phenolic compounds from the stem and bark of Musanga cecropioides R. Brown (Moraceae). Acta Poloniae Pharmaceutica, 64, 183-185. Cowan, M. M. (1999). Plant products as antimicrobial agents. Clinical Microbiology Review, 12, 564-582. 
Ejechi, B. O., \& Akpomedaye, D. E. (2005). Activity of essential oils and phenolic acid extracts of pepperfruit (Dennettia tripetala G. Baker; Annonaceae) against some food-borne microorganisms. African Journal of Biotechnology, 4 258-261. http://dx.doi.org/10.5897/AJB2005.000-3051

Gill, L. S. (1992). Ethnomedicinal uses of plants in Nigeria. Benin City. University of Benin Press, 1992. 138p

Idu, M., Gills, L. S., Omonhinmin, C. A., Ejale, A. (2000a). Ethnomedicinal uses of trees among Bachama tribe of Adamawa State, Nigeria. Indian Journal of Traditional Knowledge, 5, 273-278.

Idu, M., Omogbai, E. K. I., Aghimien, G. E., Amaechina, F., Timothy, O., \& Omonigho, S. E. (2007). Preliminary phytochemistry, antimicrobial properties and acute toxicity of Stachytarpheta jamaicensis (L) Vahl. Leaves. Trends in Medical Research, 2,193-198. http://dx.doi.org/10.3923/tmr.2007.193.198

Iwu, M. M., Duncan, A. R., \& Okunji C. O. (1999). New antimicrobials of plant origin. In J. Janick, (Ed.): Perspectives on New Crops and New Uses..,(p. 457462). Alexandria Virginia: ASHS Press

Nwinuka, N. M., \& Nwiloh, B. I. (2009). Physico-chemical properties and fatty acid composition of Dennettia tripetala fruit oil (Pepper fruit). Nigerian Journal of Biochemistry and Molecular Biology, 24, 42-46.

Okwu, D. E., Morah, F. N. I. \& Anam, E. M. (2005). Isolation and characterization of phenanthrenic alkaloid; uvariopsine from Dennettia tripetala fruits. Journal of Medicine and Aromatic Plant Science, 27, 496-498.

Ozumba U. C. (2003). Antibiotic sensitivity of isolates of Pseudomonas aeruginosa in Enugu, Nigeria. African Journal of Clinical and Experimental Microbiology,4, 48-51. http://dx.doi.org/10.4314/ajcem.v4i1.7323

Pessini, G. L., Dias Filho, B. P., Nakamura, C. V., \& Cortez, D. A. G. (2003) Antibacterial activity of extracts and neolignans from Piper regnellii (Miq.) C.

DC. var. pallescens ( C. DC.) Yunck. Memorial do Instituto Oswaldo Cruz, 98 1115-1120. http://dx.doi.org/10.1590/s0074-02762003000800025

Sofowora, E. A. (1982). Medicinal Plants and Traditional Medicines in Africa. Ibadan: Spectrum Books Limited. $250 \mathrm{p}$.

Stoke, E. J.(1975). Clinical Bacteriology. fourth edition. London: Edward Arnold Publishers. 2000 p.

Tijjani, M., Bello, I., Aliyu, A., Olurishe, T., Maidawa, S., Habila, J., \& Balogun, E. (2009). Phytochemical and antibactericidal studies of root extract of Cochlospermum tinctorium A. Rich (Cochlospermaceae). Research Journal of Medicinal Plants, 3, 16-22. http://dx.doi.org/10.3923/rjmp.2009.16.22

Trease, G. E., \& Evans, W. C. (1996). A Textbook of Pharmacognosy. London: Macmillian Publishers Limited. $850 \mathrm{p}$.

Umoh, I. B. (1998). Commonly used fruits in Nigeria. In A. U. OSAGIE, \& O. U. EKA (Eds): Nutritional Quality of Plant foods. Benin-city: University of Benin Press. 28 p.

Vandepitte, J., Verhaegen, J., Engbaek, K., Rohner, P., Piot, P., Heuck, C. C. (2003). Basic laboratory procedures in clinical bacteriology. Geneva, WHO, $175 \mathrm{p}$ 